\title{
THE INFLUENCE OF CORTISONE UPON THE DIURNAL RHYTHM OF RENAL EXCRETORY FUNCTION
}

\author{
By JACK D. ROSENBAUM, BRUCE C. FERGUSON, ROBERT K. DAVIS, AND \\ ELSIE C. ROSSMEISL \\ (From the Medical Service and Research Laboratory, Cushing Veterans Administration Hospital, \\ Framingham, Mass.)
}

(Submitted for publication January 21, 1952; accepted March 24, 1952)

Vogel in 1854 (1) observed that the flow of urine at night was usually less than that by day. $\mathrm{He}$ attributed this nocturnal oliguria chiefly to decreased fluid intake, but Roberts in 1860 (2) and Quincke in 1877 (3) showed that urine flow increased in the morning even when no food or fluid was taken. This matutinal diuresis did not occur if the subject went back to sleep (3). Moreover, although the specific gravity of the night urine was higher than that of the morning urine, the change in density was relatively smaller than that in volume, indicating that excretion of total solids as well as of water was decreased during the night $(2,4-6)$. Reversal of the normal excretory pattern was described in patients with cardiac or renal disease $(5,7)$. Similar findings were reported by various authors (8-15). It has also been demonstrated repeatedly that renal excretion rates for chloride $(4,16-32)$, sodium (4, $23,24,29-33)$, and potassium (4, 23, 24, 29-33) are consistently much lower by night than by day, even when no food or electrolyte is taken or when the dietary intake is equally distributed over each 24-hour period. The output of urea characteristically declines at night $(10,12,14,17,18,28,33-$ 35 ), but Smits (29) and Borst and de Vries (30) relate this decrease in excretion, unlike that of other solutes, to nocturnal diminution of urine flow; they find that the nocturnal excretion rate, "corrected" according to the Van Slyke formula for standard urea clearance, approximates the rate by day. Uric acid excretion also falls during the night $(8,36,37)$. Phosphate excretion is ordinarily higher at night than by day $(17,18,24$, 32 ), but a nocturnal fall has been described in the fasting recumbent subject (38). Although creatinine excretion has been found to decrease slightly at night $(19,36,37,39)$, the change is minute in comparison with the large variations in excretion of water, electrolytes and uric acid. The renal clearances of endogenous creatinine (39, 40 ) and of inulin (40) normally fall slightly during the nocturnal hours; however, the decline in urine flow at night is almost entirely due to increased tubular reabsorption of water rather than to decreased filtration.

The mechanisms responsible for the normal renal excretory rhythm are obscure. Evidence which suggests that the anterior pituitary is essential for maintenance of some diurnal rhythms in certain species has been reviewed by Kleitman (41). The possible dependence of renal excretory rhythms upon diurnal variations in adrenocortical activity was considered by Borst and de Vries, but they found that nocturnal suppression of sodium and potassium excretion occurred in a patient with Addison's disease (30). Examination of other data concerning electrolyte excretion indicates that the normal diurnal rhythm may be altered in adrenalectomized rats (42) and in untreated patients with Addison's disease (43). On the other hand, of four patients with Addison's disease studied by Slessor (44), three showed a distinct matutinal increase in the rate of chloride excretion, whereas of three patients with panhypopituitarism, two showed no significant increase.

If the diurnal variations in electrolyte excretion are related to fluctuations in adrenocortical activity, they should be modified in patients who receive large doses of cortisone at regular intervals during each 24-hour period. Under these circumstances endogenous production of adrenocortical hormones should be minimal (45-47), and variations in endogenous production would probably be unimportant with continuing absorption from large intramuscular depots, or frequent oral administration. The observations which form the basis of this report indicate that the normal diurnal variations in renal excretion of electrolytes are indeed greatly modified during cortisone ad- 
ministration, but that the changes are probably not due to a direct influence of cortisone upon the renal excretory mechanism.

\section{MATERIALS AND METHODS}

The subjects were seven male patients, three with rheumatoid arthritis, and one each with asthmatic bronchitis, allergic rhinitis, neurodermatitis, and benign pemphigus. All were free from renal and cardiovascular disease. Each was studied during the administration of cortisone acetate (Cortone, Merck) at six- or 12-hour intervals beginning at 6 a.m. daily. The intramuscular route was employed in all except $Z$., the patient with pemphigus, who received $50 \mathrm{mg}$. orally every six hours. Subjects A., C., and D. received $100 \mathrm{mg}$. every 12 hours, while B., X., and $Y$. received $125 \mathrm{mg}$. every six hours. Control observations were made before and after the course of cortisone administration in three patients and after the course of therapy, but not before, in four. One of the subjects was also studied while receiving desoxycorticosterone acetate, $10 \mathrm{mg}$. intramuscularly every six hours. Three of the patients received each day a diet of unrestricted salt content estimated to contain 130 to 250 meq. of sodium; the others partook of a diet containing approximately 35 meq. of sodium, with or without a supplement of 43 meq. (as 0.45 per cent saline) at 6 a.m., noon, 6 p.m. and midnight. Meals were taken at 7 a.m., noon, and 5 p.m., with free access to water at all times. The patients were ambulatory during the day and remained in bed from 10 p.m. to 6 a.m. Occasional wakefulness at night was controlled by chloral hydrate in doses of $0.6 \mathrm{gm}$. or secobarbital sodium in doses of $0.1 \mathrm{gm}$. Except when otherwise noted, pooled specimens of voided urine were collected from 6 a.m. to 10 p.m. and from 10 p.m. to 6 a.m. during each 24-hour period.

In each of two experiments a subject was studied over periods of 48 to 54 hours, during which he remained at strict bed rest and ate identical meals ${ }^{1}$ at 6 a.m., noon, 6 p.m. and midnight. Fluid intake was constant ( 720 or $960 \mathrm{ml}$.) during each six-hour period and $43 \mathrm{meq}$. of sodium chloride were ingested at 7 a.m., 1 p.m., 7 p.m., and 1 a.m. Urine collections were made during consecutive

1 The meals consisted of milk and sandwiches which were made up by taking measured aliquots of single lots of bread, egg salad, cheese and jam. The feedings taken by subject $Y$. were calculated to contain $28 \mathrm{gm}$. protein, $36 \mathrm{gm}$. fat, $72 \mathrm{gm}$. carbohydrate, $24 \mathrm{meq}$. sodium and 14 meq. potassium per meal. The meals eaten by subject $\mathrm{X}$. while he was receiving cortisone each contained 30 gm. protein, $40 \mathrm{gm}$. fat, $72 \mathrm{gm}$. carbohydrate, 62 meq. sodium and 17 meq. potassium. During his control study each meal contained $23 \mathrm{gm}$. protein, $25 \mathrm{gm}$. fat, $85 \mathrm{gm}$. carbohydrate, 53 meq. sodium and 14 meq. potassium.

TABLE I

Relation of cortisone administration to the diurnal variation of renal excretion in ambulatory patients

\begin{tabular}{|c|c|c|c|c|c|c|c|c|c|c|c|c|}
\hline \multirow{3}{*}{$\begin{array}{l}\text { Patient and } \\
\text { diagnosis }\end{array}$} & \multirow{3}{*}{$\begin{array}{c}\text { Cortisone } \\
\text { dosage } \\
(m g . / d a y)\end{array}$} & \multirow{3}{*}{$\begin{array}{l}\text { Collection period } \\
\text { (inclusive treatment days) }\end{array}$} & \multicolumn{10}{|c|}{ Mean renal excretion rates of } \\
\hline & & & \multicolumn{2}{|c|}{$\underset{(m l . / m i n .)}{\text { Water }}$} & \multicolumn{2}{|c|}{$\begin{array}{l}\text { Creatinine } \\
(m g . / \min .)\end{array}$} & \multicolumn{2}{|c|}{$(\mu \underset{q}{\mathrm{Na} . / \min .})$} & \multicolumn{2}{|c|}{$\underset{(\mu E q . / \min .)}{\mathrm{Cl}}$} & \multicolumn{2}{|c|}{$(\mu E q . / \min )}$. \\
\hline & & & Day* & Night* & Day & Night & Day & Night & Day & Night & Day & Night \\
\hline \multirow{2}{*}{$\begin{array}{l}\text { A. } \dagger \\
\text { Asthmatic } \\
\text { bronchitis }\end{array}$} & 200 & 38th-40th & 2.2 & 2.8 & 1.20 & 1.01 & 158 & 204 & 180 & 220 & 96 & 85 \\
\hline & None & +18th-19th & 1.1 & 1.0 & 1.00 & 0.90 & 115 & 91 & 135 & 90 & 56 & 22 \\
\hline \multirow{2}{*}{$\begin{array}{l}\quad \text { B.f } \\
\text { Rheumatoid } \\
\text { arthritis }\end{array}$} & & & & 1.7 & & & 31 & 67 & 34 & 81 & 56 & 73 \\
\hline & None & +15 th -17 th & 1.2 & 0.7 & 1.07 & 0.99 & 40 & 16 & 56 & 21 & 74 & 48 \\
\hline \multirow{2}{*}{$\begin{array}{l}\text { C.† } \\
\text { Neuro- } \\
\text { dermatitis }\end{array}$} & & & & & & & & 250 & 347 & 281 & 92 & 97 \\
\hline & None & +11 th, 12th, 15th & 1.0 & 0.7 & 1.33 & 1.20 & 215 & 90 & 245 & 85 & 64 & 23 \\
\hline \multirow{2}{*}{$\begin{array}{l}\text { D.† } \\
\text { Allergic } \\
\text { rhinitis }\end{array}$} & & & & & & & 91 & 177 & 92 & 151 & 62 & 71 \\
\hline & None & +7 th-8th & 1.8 & 4.0 & 1.47 & 1.35 & 265 & 312 & 299 & 283 & 142 & 119 \\
\hline \multirow{2}{*}{$\begin{array}{l}\quad \mathrm{X} .8 \\
\text { Rheumatoid } \\
\text { arthritis }\end{array}$} & 500 & 13th-16th & 2.0 & 4.1 & 1.05 & 0.95 & 69 & 195 & 112 & 290 & 66 & 106 \\
\hline & None & +21st-24th & 2.6 & 1.5 & 1.01 & 0.86 & 144 & 41 & 155 & 53 & 89 & 37 \\
\hline $\begin{array}{l}\quad \text { Y. } \$ \\
\text { Rheumatoid } \\
\text { arthritis }\end{array}$ & $\begin{array}{l}\text { None } \\
500 \\
500\end{array}$ & $\begin{array}{c}-7 \text { th to }-4 \text { th } \\
10 \text { th } \\
14 \text { th }\end{array}$ & $\begin{array}{l}2.8 \\
2.2 \\
2.8\end{array}$ & $\begin{array}{l}2.0 \\
3.0 \\
4.3\end{array}$ & $\begin{array}{l}0.86 \\
0.87 \\
0.99\end{array}$ & $\begin{array}{l}0.83 \\
0.84 \\
0.90\end{array}$ & $\begin{array}{l}142 \\
107 \\
115\end{array}$ & $\begin{array}{r}73 \\
128 \\
303\end{array}$ & $\begin{array}{l}166 \\
150 \\
149\end{array}$ & $\begin{array}{r}71 \\
179 \\
351\end{array}$ & $\begin{array}{l}66 \\
85 \\
90\end{array}$ & $\begin{array}{r}35 \\
98 \\
116\end{array}$ \\
\hline
\end{tabular}

* "Day" period, 6 a.m.-10 p.m.; "night" period, 10 p.m.-6 a.m.

Unrestricted salt intake.

$\ddagger$ Low salt diet.

Low salt diet plus 43 meq. $\mathrm{NaCl}$ every six hours. 
TABLE II

Relation of adrenocortical hormone administration to diurnal variation of renal excretion. Subject $Z$. Benign pemphigus

\begin{tabular}{|c|c|c|c|c|c|c|c|c|c|c|c|c|c|c|c|}
\hline & \multirow{3}{*}{$\begin{array}{c}\text { Period } \\
\text { Low salt* }\end{array}$} & \multirow{2}{*}{\multicolumn{2}{|c|}{ Days }} & \multicolumn{10}{|c|}{ Renal excretory rates (mean \pm standard error) of } & \multirow{3}{*}{$\begin{array}{c}\begin{array}{c}\text { Creat. } \\
\text { clear. } \\
6 \text { a.m.- } \\
\text { noon }\end{array} \\
\begin{array}{c}(m l . / \\
\text { min. }) \\
111 \pm 4.8\end{array}\end{array}$} & \multirow{3}{*}{$\begin{array}{c}\begin{array}{c}\text { Weight } \\
\text { (range) }\end{array} \\
\left(K_{g .}\right) \\
67.5-68.0\end{array}$} \\
\hline & & & & \multicolumn{2}{|c|}{ Water } & \multicolumn{2}{|c|}{ Sodium } & \multicolumn{2}{|c|}{ Chloride } & \multicolumn{2}{|c|}{ Potassium } & \multicolumn{2}{|c|}{ Creatinine } & & \\
\hline I & & $\begin{array}{cc}1-5 & I \\
& I\end{array}$ & $\mathbf{D}$ & $\begin{array}{c}(\operatorname{ml} . / \\
\min .) \\
2.6 \pm 0.3 \\
1.3 \pm 0.1\end{array}$ & $\begin{array}{l}\mathrm{P} \\
<.01\end{array}$ & $\begin{array}{c}(\mu E q . / \\
\min .) \\
10 \pm 0.6 \\
6 \pm 0.8\end{array}$ & $\begin{array}{l}\mathrm{P} \\
<.01\end{array}$ & $\begin{array}{l}(\mu E q .) \\
\min .) \\
14 \pm 1.0 \\
9 \pm 0.7\end{array}$ & $\begin{array}{l}\mathrm{P} \\
<.01\end{array}$ & $\begin{array}{c}(\mu E q . / \\
\min .) \\
51 \pm 2.1 \\
30 \pm 0.9\end{array}$ & $\begin{array}{c}P \\
<.01\end{array}$ & $\begin{array}{l}\text { (mg./min.) } \\
1.38 \pm 0.04 \\
1.11 \pm 0.04\end{array}$ & $\begin{array}{c}P \\
<.01\end{array}$ & & \\
\hline II & $\begin{array}{l}\text { Low salt } \\
\text { DCA }\end{array}$ & 6-14 I & $\stackrel{\mathrm{D}}{\mathbf{N}}$ & $\begin{array}{l}2.8 \pm 0.2 \\
1.5 \pm 0.1\end{array}$ & $<.01$ & $\begin{array}{l}7 \pm 1.0 \\
4 \pm 0.4\end{array}$ & $<.01$ & $\begin{array}{r}11 \pm 1.0 \\
8 \pm 0.6\end{array}$ & $<.02$ & \begin{tabular}{l|}
$69 \pm 3.7$ \\
$48 \pm 1.0$
\end{tabular} & $<.01$ & $\begin{array}{l}1.46 \pm 0.02 \\
1.19 \pm 0.03\end{array}$ & $<.01$ & $111 \pm 2.2$ & $67.5-68.8$ \\
\hline III & Low salt & $15-19$ & $\mathbf{D}$ & $\begin{array}{l}2.5 \pm 0.2 \\
1.5 \pm 0.1\end{array}$ & $<.01$ & $\begin{array}{l}44 \pm 3.8 \\
28 \pm 4.2 \\
\end{array}$ & $<.05$ & $\begin{array}{l}43 \pm 3.5 \\
25 \pm 4.2 \\
\end{array}$ & $<.02$ & $\begin{array}{l}64 \pm 2.6 \\
39 \pm 1.8 \\
\end{array}$ & $<.01$ & $\begin{array}{l}1.39 \pm 0.03 \\
1.21 \pm 0.06 \\
\end{array}$ & $<.05$ & $119 \pm 5.7$ & $67.7-68.4$ \\
\hline$\overline{\mathbf{v}}$ & $\begin{array}{l}\text { Low salt } \\
\text { Cortisonet }\end{array}$ & $34-38$ & & $\begin{array}{l}2.3 \pm 0.1 \\
2.0 \pm 0.2\end{array}$ & $>0.1$ & $\begin{array}{l}15 \pm 1.6 \\
21 \pm 2.1\end{array}$ & $>.05$ & $\begin{array}{l}17 \pm 1.8 \\
20 \pm 2.4\end{array}$ & $>0.3$ & $\begin{array}{l}48 \pm 3.1 \\
42 \pm 4.7\end{array}$ & $>0.3$ & $\begin{array}{l}1.42 \pm 0.03 \\
1.20 \pm 0.05\end{array}$ & $<.01$ & $123 \pm 4.5$ & $66.4-66.8$ \\
\hline VI & $\begin{array}{l}\text { Low salt } \\
\text { Cortisone } \\
\text { K supplementt }\end{array}$ & $39-44$ & $\stackrel{\mathrm{D}}{\mathbf{N}}$ & $\begin{array}{l}2.7 \pm 0.1 \\
2.4 \pm 0.1\end{array}$ & $>0.1$ & $\begin{array}{l}20 \pm 1.5 \\
28 \pm 4.4\end{array}$ & $>0.1$ & $\begin{array}{l}21 \pm 1.7 \\
22 \pm 5.2\end{array}$ & $>0.5$ & $\begin{array}{l}67 \pm 12.2 \\
67 \pm 8.7\end{array}$ & $>0.9$ & $\begin{array}{l}1.45 \pm 0.07 \\
1.22 \pm 0.06\end{array}$ & $<.05$ & $135 \pm 6.7$ & $65.6-66.1$ \\
\hline VII & $\begin{array}{l}\text { Cortisone } \\
\text { NaCl\& and } \mathrm{K} \\
\text { supplement }\end{array}$ & 47-59 & $\mathbf{D}$ & $\begin{array}{l}2.8 \pm 0.2 \\
2.8 \pm 0.1\end{array}$ & $>0.9$ & $\begin{array}{l}116 \pm 3.2 \\
154 \pm 7.3\end{array}$ & $<.01$ & $\begin{array}{l}113 \pm 3.3 \\
167 \pm 8.4\end{array}$ & $<.01$ & $\begin{array}{l}64 \pm 2.4 \\
72 \pm 3.4\end{array}$ & $<0.1$ & $\begin{array}{l}1.44 \pm 0.02 \\
1.29 \pm 0.04\end{array}$ & $<.01$ & $128 \pm 4.9$ & $65.8-68.3$ \\
\hline VIII & $\begin{array}{l}\text { Cortisone omit- } \\
\text { ted. NaCl and } \\
\mathrm{K} \text { supplement }\end{array}$ & 66-72 I & $\mathbf{D}$ & $\begin{array}{l}2.8 \pm 0.2 \\
1.7 \pm 0.2\end{array}$ & $<.01$ & $\begin{array}{r}124 \pm 6.0 \\
68 \pm 6.1\end{array}$ & $<.01$ & $\begin{array}{r}132 \pm 7.3 \\
68 \pm 5.5\end{array}$ & $<.01$ & $\begin{array}{l}71 \pm 3.5 \\
45 \pm 2.3\end{array}$ & $<.01$ & $\begin{array}{l}1.56 \pm 0.04 \\
1.39 \pm 0.04\end{array}$ & $<.05$ & $136 \pm 8.0$ & $68.2-69.0$ \\
\hline IX & $\begin{array}{l}\text { Low salt } \\
\text { Komitted 79th } \\
\text { dayll }\end{array}$ & $\overline{76-83}$ & & $\begin{array}{l}2.5 \pm 0.1 \\
1.3 \pm 0.1\end{array}$ & $<.01$ & $\begin{array}{r}11 \pm 1.7 \\
5 \pm 0.5\end{array}$ & $<.01$ & $\begin{array}{r}15 \pm 1.2 \\
6 \pm 0.5\end{array}$ & $<.01$ & $\begin{array}{l}60 \pm 1.3 \\
36 \pm 1.3\end{array}$ & $<.01$ & $\begin{array}{l}1.40 \pm 0.03 \\
1.16 \pm 0.05\end{array}$ & $<.01$ & $113 \pm 2.9$ & $68.2-68.8$ \\
\hline
\end{tabular}

Data pertaining to Period IV are presented in Figure 4.

P-Probability of observed or greater difference between means of night and day values being found assuming hypothetical difference of zero (as determined by " $t$ " test of group comparison). Bold type indicates that nocturnal excretion rate is not significantly lower than day rate.

D-Day, 6 a.m.-midnight.

N-Night, midnight-6 a.m.

DCA-Desoxycorticosterone acetate in oil, $10 \mathrm{mg}$. intramuscularly every 6 hours, days 6 through 14.

* Sodium content approximately 35 meq.

† Cortisone acetate, $50 \mathrm{mg}$. orally every 6 hours, days 25 through 59.

$\$ 500 \mathrm{ml}$. orange juice at 10 p.m., days 39 through 78 .

43 meq. sodium chloride every 6 hours, days 45 through 72 .

$\|$ Excretion rates for $K$, days 76-78: $57 \pm 1.8$ (day), $38 \pm 4.3$ (night), $P<.01$; days 79-83: $62 \pm 1.5$ (day), $35 \pm 1.1$ (night), $\mathrm{P}<.01$.

six-hour periods beginning at 6 a.m. on the first day of the regime. Samples of venous blood were taken at the beginning and end of each six-hour collection period.

Concentrations of sodium and potassium in serum and urine were determined by means of an internal standard flame photometer. Chloride was determined by the modified Volhard-Harvey titration (48). The method of Peters (49) was employed for the determination of creatinine in urine; for serum, the Hare technique (50) was applied. Calculations of endogenous creatinine clearances were based either on the mean of serum concentrations at the beginning and end of each collection period, or on the concentration in a single sample taken at the approximate mid-point of the period.

\section{RESULTS}

\section{Observations in ambulatory patients}

Studies conducted before and after cortisone administration (subject Z.), prior to cortisone therapy (subject $Y$.), and 11 days or longer after discontinuing cortisone administration (subjects A., B., C., and X.), demonstrated a normal diurnal pattern of renal excretion (Tables $I$ and $I I$ ). The rate of urine flow was uniformly less by night than by day. The rate of creatinine excretion was slightly depressed at night. Excretion rates of sodium, potassium, and chloride fell markedly at night. The study of subject D., conducted on the seventh and eighth days after cortisone administration had been discontinued, when endogenous adrenocortical activity may well have been suppressed $(45-47,51)$, will be described below.

All seven subjects displayed striking deviations from normal excretory patterns during cortisone administration. Urine flow at night became approximately equal to the rate by day in subjects $D$. and $Z$. and exceeded the day rate in the others. A higher minute output of sodium and chloride by night than by day was observed in all subjects 
TABLE III

Diurnal variation of renal excretion in two subjects at bed rest taking identical food and fuids during consecutive six-hour periods

\begin{tabular}{|c|c|c|c|c|c|c|c|c|c|c|c|}
\hline & & & \multicolumn{4}{|c|}{ 1st day } & \multicolumn{4}{|c|}{ 2nd day } & \multirow{2}{*}{$\frac{3 r d \text { day }}{6 \text { a.m.-9 a.m. }}$} \\
\hline & & & $\begin{array}{l}6 \text { a.m.- } \\
12 \mathrm{n} .\end{array}$ & $\begin{array}{l}12 \mathrm{n} .- \\
6 \mathrm{p} . \mathrm{m} .\end{array}$ & $\begin{array}{l}6 \text { p.m.- } \\
12 \mathrm{~m} .\end{array}$ & $\begin{array}{l}12 \mathrm{~m} .- \\
6 \mathrm{a} . \mathrm{m} .\end{array}$ & $\begin{array}{l}6 \text { a.m.- } \\
12 \mathrm{n} .\end{array}$ & $\begin{array}{l}12 \mathrm{n.}- \\
6 \text { p.m. }\end{array}$ & $\begin{array}{l}6 \text { p.m.- } \\
12 \mathrm{~m} .\end{array}$ & $\begin{array}{l}12 \mathrm{~m} \cdot- \\
6 \text { a.m. }\end{array}$ & \\
\hline \multirow{2}{*}{ Y. } & $\begin{array}{r}\text { Control } \\
\text { cortis }\end{array}$ & $\begin{array}{l}\mathrm{Na} \mu E q . / \min . \\
\mathrm{Cl} \mu E q . / \min . \\
\mathrm{K} \mu E q . / \min . \\
\mathrm{CR} \text { mg./min. } \\
\text { Flow ml./min. } \\
\mathrm{C}_{\mathrm{CR}} \text { ml. } / \text { min. }\end{array}$ & $\begin{array}{c}106 \\
121 \\
37 \\
0.96 \\
1.2 \\
110\end{array}$ & $\begin{array}{c}156 \\
148 \\
33 \\
0.88 \\
1.6 \\
111\end{array}$ & $\begin{array}{c}154 \\
135 \\
18 \\
0.85 \\
2.2 \\
114\end{array}$ & \begin{tabular}{|c|}
77 \\
91 \\
12 \\
0.87 \\
1.2 \\
119
\end{tabular} & $\begin{array}{c}217 \\
239 \\
36 \\
0.96 \\
1.4 \\
137\end{array}$ & $\begin{array}{c}125 \\
124 \\
16 \\
0.78 \\
1.8 \\
115\end{array}$ & $\begin{array}{l}172 \\
146 \\
17 \\
0.79 \\
1.8 \\
113\end{array}$ & $\begin{array}{l}92 \\
95 \\
12 \\
0.75 \\
1.5 \\
109\end{array}$ & $\begin{array}{l}123 \\
151 \\
22 \\
0.82 \\
0.9 \\
121\end{array}$ \\
\hline & $\begin{array}{c}\text { Cortisone } \\
11 \text { th }-13 \text { th day }\end{array}$ & $\begin{array}{l}\mathrm{Na} \mu E q . / \min . \\
\mathrm{Cl} \mu E q . / \min . \\
\mathrm{K} \mu E q . / \min . \\
\mathrm{CR} \text { mg./min. } \\
\text { Flow ml. } / \text { min. } \\
\mathrm{C}_{\mathrm{CR}} \text { ml. } / \text { min. }\end{array}$ & $\begin{array}{c}24 \\
43 \\
45 \\
0.87 \\
0.7 \\
148\end{array}$ & $\begin{array}{c}18 \\
34 \\
32 \\
0.67 \\
0.5 \\
116\end{array}$ & $\begin{array}{c}30 \\
57 \\
42 \\
0.65 \\
0.9 \\
112\end{array}$ & $\begin{array}{c}37 \\
66 \\
43 \\
0.72 \\
1.2 \\
126\end{array}$ & \begin{tabular}{|c|}
54 \\
93 \\
46 \\
0.83 \\
0.9 \\
154
\end{tabular} & $\begin{array}{c}43 \\
80 \\
39 \\
0.74 \\
1.1 \\
145\end{array}$ & $\begin{array}{c}85 \\
148 \\
46 \\
0.80 \\
1.2 \\
160\end{array}$ & $\begin{array}{c}70 \\
116 \\
41 \\
0.76 \\
1.8 \\
149\end{array}$ & $\begin{array}{c}54 \\
80 \\
42 \\
0.84 \\
0.7 \\
165\end{array}$ \\
\hline \multirow{2}{*}{ X. } & $\begin{array}{l}\text { Control } \mathbf{6} \text { wks. } \\
\text { after cortisone }\end{array}$ & $\begin{array}{l}\mathrm{Na} \mu E q . / \min . \\
\mathrm{Cl} \mu E q . / \min . \\
\mathrm{K} \mu E q . / \min . \\
\mathrm{CR} \text { mg. } \mathrm{min} . \\
\mathrm{Flow} \mathrm{ml./min.} \\
\mathrm{C}_{\mathrm{CR}} \text { ml. } / \text { min. }\end{array}$ & $\begin{array}{c}167 \\
233 \\
98 \\
0.95 \\
2.7 \\
172\end{array}$ & $\begin{array}{c}144 \\
160 \\
46 \\
0.92 \\
1.9 \\
167\end{array}$ & $\begin{array}{c}95 \\
89 \\
32 \\
0.93 \\
1.0 \\
169\end{array}$ & $\begin{array}{c}94 \\
94 \\
28 \\
0.88 \\
1.5 \\
162\end{array}$ & $\begin{array}{c}300 \\
377 \\
72 \\
0.92 \\
3.5 \\
170\end{array}$ & $\begin{array}{c}173 \\
192 \\
34 \\
0.93 \\
2.2 \\
169\end{array}$ & $\begin{array}{c}117 \\
102 \\
29 \\
0.89 \\
1.4 \\
154\end{array}$ & $\begin{array}{c}84 \\
96 \\
27 \\
0.89 \\
1.3 \\
162\end{array}$ & $\begin{array}{l}267^{*} \\
292^{*} \\
55^{*} \\
0.77^{*} \\
3.5^{*} \\
140^{*}\end{array}$ \\
\hline & $\mid \begin{array}{c}\text { Cortisone } \\
\text { 23rd-24th day }\end{array}$ & $\begin{array}{l}\mathrm{Na} \mu E q . / \min . \\
\mathrm{Cl} \mu E q . / \min . \\
\mathrm{K} \mu E q . / \min . \\
\mathrm{CR} \text { mg./min. } \\
\mathrm{Flow}^{2} / \mathrm{ml} / \mathrm{min} . \\
\mathrm{C}_{\mathrm{CR}} \text { ml. } / \text { min. }\end{array}$ & $\begin{array}{c}92 \\
97 \\
55 \\
0.93 \\
1.5 \\
158\end{array}$ & $\begin{array}{c}159 \\
158 \\
63 \\
0.92 \\
1.8 \\
174\end{array}$ & $\begin{array}{c}155 \\
200 \\
73 \\
0.92 \\
1.9 \\
174\end{array}$ & $\begin{array}{c}115 \\
150 \\
63 \\
0.90 \\
1.7 \\
177\end{array}$ & $\begin{array}{c}156 \\
184 \\
62 \\
0.97 \\
1.8 \\
210\end{array}$ & $\begin{array}{c}245 \\
298 \\
78 \\
0.95 \\
2.4 \\
225\end{array}$ & $\begin{array}{c}316 \\
343 \\
87 \\
0.91 \\
2.7 \\
217\end{array}$ & $\begin{array}{c}163 \\
201 \\
59 \\
0.80 \\
1.7 \\
178\end{array}$ & \\
\hline
\end{tabular}

*6 a.m.-11:35 a.m.

CR-Creatinine; $\dot{C}_{\mathrm{CR}}-$ Endogenous creatinine clearance.

except C. whose nocturnal excretion rates, although markedly increased, remained below the rate by day. Nocturnal rates of potassium excretion were approximately equal to the day rate in A., C., D., and Z. and exceeded the day rate in the others. No significant modification in the pattern of creatinine excretion was noted.

\section{Observations during continued recumbency with equally spaced identical meals}

Similar alterations in the diurnal excretory rhythm occurred when two of the subjects took identical food and fluid at six-hour intervals while at bed rest. During the control study before cortisone administration, Y. manifested a striking decrease in the excretion of sodium and chloride during the night periods (Table III, Figure 1). Potassium output characteristically increased abruptly during the morning and fell during the afternoon and evening, as well as at night. These variations were unassociated with alterations in creatinine excretion or clearance. While cortisone was being given, a remarkably constant rate of potassium excretion was maintained during nine consecutive periods. The excretion of sodium and chloride exhibited no regular diurnal rhythm, although a distinct rise took place on the morning of the second day and the still higher excretion rates during the period from 6 p.m. to midnight on this day were followed by a decline during the subsequent period from midnight to 6 a.m. Urine flow rose during each night period, while creatinine excretion showed no notable alteration.

During the control study of $\mathrm{X}$., potassium excretion was highest during the morning periods, but while cortisone was being given, a comparatively constant excretion rate was maintained until the second night period (Table III). The unusually small creatinine output recorded for this period suggests that the bladder was incompletely emptied. Creatinine excretion otherwise re- 
mained quite constant during both the experimental and control observations. Urine flow declined markedly at night during the control period, but not during cortisone administration. The excretion of sodium and chloride decreased during the periods from 6 p.m. to midnight in the control study but not when cortisone was given. However, lowering of the excretion rates between midnight and 6 a.m. occurred whether or not cortisone was being administered.

\section{Serial daily observations before, during, and after cortisone administration}

Additional data concerning the temporal relationship of cortisone therapy to the observed changes in renal excretory function were obtained for $\mathrm{Y}$. during eight consecutive days prior to cortisone administration, during the next 14 days while he received cortisone, and during the following 18 days after cortisone was discontinued (Figure 2). When cortisone administration was begun, he excreted little sodium and gained weight. Despite continued administration of the agent, sodium excretion subsequently increased and weight gain ceased.

The changes observed in diurnal excretory rhythm were as follows. The diurnal variation of sodium excretion was altered rapidly; the nocturnal rate approximately equalled or actually exceeded the rate of the antecedent daytime period during and after the 11th day of observation (third day of treatment). This abolition or reversal of the normal diurnal rhythm persisted until the 32nd day (tenth day after cortisone was discontinued) and a consistently normal rhythm was re-established during the 38th through 40th days (16th-18th days after therapy). Changes in chloride excretion are not shown in the figure since they paralleled sodium very closely. The diurnal rhythm of water excretion was eliminated from the tenth through the 38 th day. The period during which the diurnal rhythm of sodium output was abnormal (11th-31st days, inclusive) coincided very closely with the time during which body weight was increased, presumably owing to retention of sodium chloride and water. Endogenous creatinine clearance was consistently elevated during most of this period. The marked diurnal variation in potassium excretion, evident during the eight-day pre-treatment control pe-

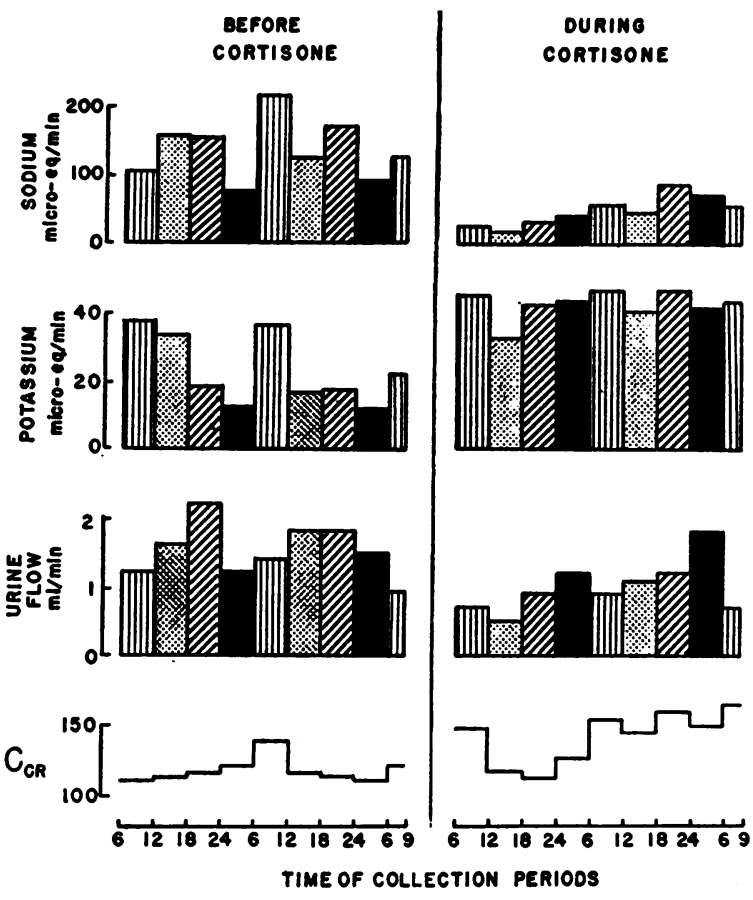

Fig. 1. Subject Y. Diurnal Excretory Pattern Before and During Cortisone Administration when Identical Food and Fluid were Taken Every Six Hours and Recumbent Posture Maintained ThroughOUT

riod (except on the third day), was strikingly diminished on the ninth and tenth days (first two days of treatment), and was eliminated or reversed from the 11 th through the 24 th day (third day of treatment through the second day after treatment). From the 25th through the 33rd day, the pattern varied until a consistently normal rhythm had been restored by the 34th day of observation (12th post-treatment day). Concentrations of serum electrolyte were measured at intervals of approximately one week. During the two weeks of treatment, serum sodium rose from 141 to 147 meq. per liter while potassium fell from 4.7 to 3.2 meq. per liter. During this period, the hematocrit fell from 38 to 34 per cent and hemoglobin from 11.3 to $9.8 \mathrm{gm}$. per $100 \mathrm{ml}$. No further change occurred during the first four days after cortisone was discontinued but after two more weeks all values approximated the initial levels.

In X., who was studied the day before instituting therapy, during 24 days of treatment and for 24 days after treatment ended, similar changes 

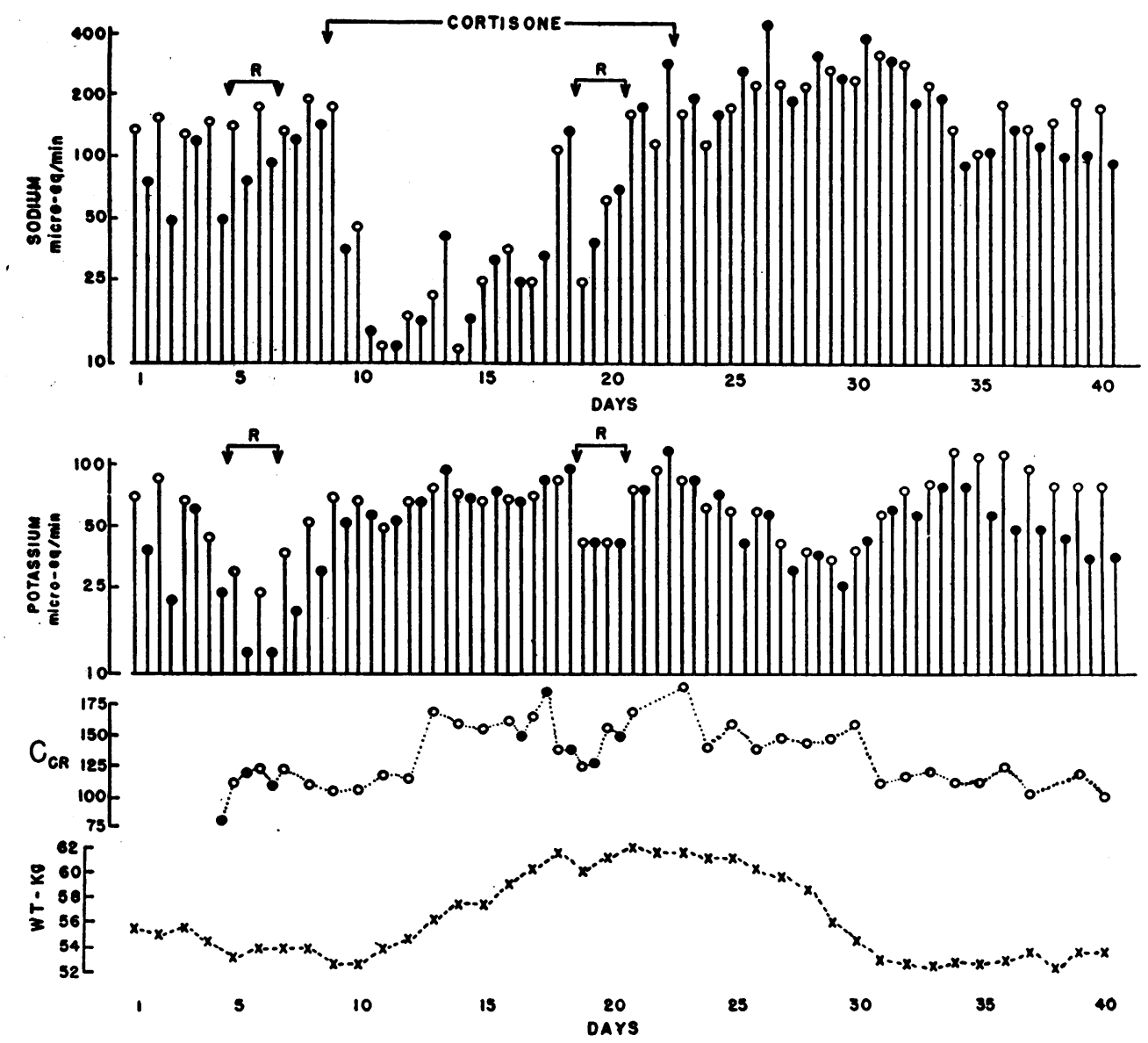

Fig. 2. Subject Y. Serial Daily Observations of Diurnal Excretory Rhythm Before, During, and After Cortisone Administration

Open circles represent day values. Solid circles, night values. Logarithmic ordinate scale for sodium and potassium excretion rates. During periods marked " $R$ " identical food and fluid were taken every six hours and recumbent posture was maintained.

occurred, but the temporal relationships were somewhat different (Figure 3 ). Sodium retention was less marked than in Y., and weight gain less rapid. Moreover X., who was treated for ten days longer than $Y$., continued to excrete large amounts of sodium after the first two weeks and lost 4 kilograms of weight during the last six days of therapy. A normal diurnal rhythm of sodium excretion was maintained during the first ten days of cortisone administration. Reversal occurred abruptly on the 13th day (12th day of treatment) and persisted through the 33rd day (eighth post-treatment day). After three days during which excretory rates by day and night were approximately equal, a small decrease in nocturnal excretion occurred on the 37 th day (12th post-treatment day) and a marked nocturnal fall occurred regularly thereafter. Chloride excretion throughout the study was similar to that of sodium and the alterations in the rhythm of water excretion coincided with these also. However, the period of altered excretory rhythm for sodium and chloride did not coincide with increased body weight as in the case of $Y$. Weight had increased by almost 6 kilograms during the first ten days of treatment without change in the normal excretory rhythm. It is noteworthy that the patient remained at bed rest during this time and did not become ambulatory until the 13th day, after the rhythm had reversed. The return to a normal rhythm after treatment did coincide with the final stabilization of body weight. Al- 
though creatinine clearance was not measured before treatment, the available observations suggest that an increase to levels above the normal had occurred by the fourth day of treatment. A gradual decline to normal levels was observed after cortisone was discontinued. The normal rhythm of potassium excretion was eliminated on the fourth day (third day of treatment) and became reversed on the 13th day, remaining so through the 33rd day (eighth day after treatment was discontinued). During the next four days the excretion rates by day and by night were approximately equal; a variable relationship obtained for the eight days following, after which a consistently normal pattern was observed.

The studies on Z. (Table II, Figure 4) were begun while he was taking a diet poor in sodium without the salt supplement received by $X$. and
Y. Following a control period of five days, he was given desoxycorticosterone acetate in oil, 10 mg. intramuscularly every six hours, for nine days. During this time a normal diurnal rhythm persisted (periods I and II, Table II). Increased potassium excretion during DCA administration and increased excretion of sodium and chloride when DCA was discontinued (period III, Table II) were unassociated with any change in the diurnal excretory pattern. Weight changes were minimal during these first three periods as well as after cortisone administration was begun on the 25th day of observation in oral doses of 50 mg. every six hours. The nocturnal decrease in sodium excretion which was regularly apparent before cortisone was given and during the first three days of cortisone therapy was absent or insignificant after the ninth treatment day (Figure

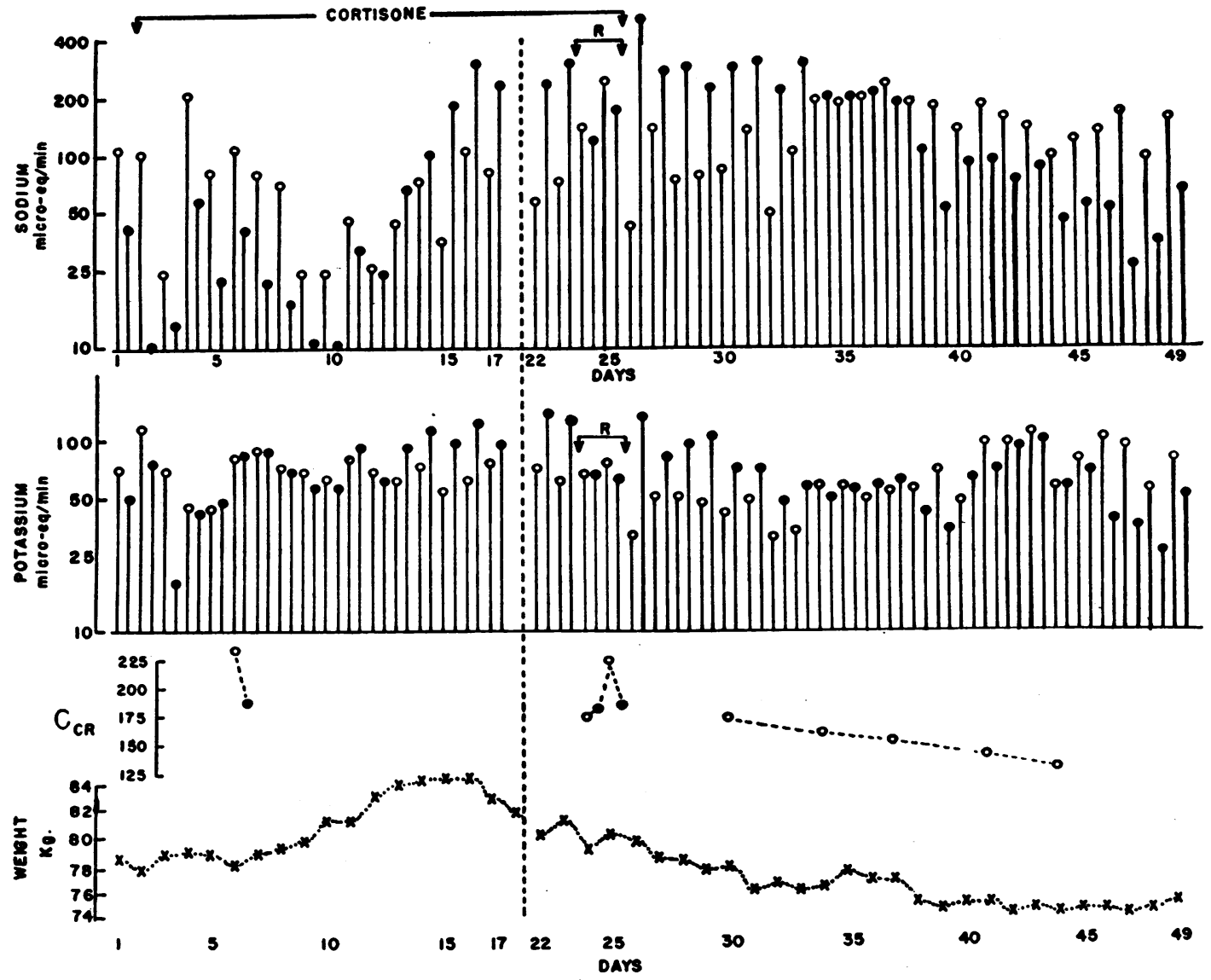

Fig. 3. Subject X. Serial Daily Observations of Diurnal Excretory Rhythm, Before, During, and After Cortisone Administration

See Figure 2 for legend. The dotted vertical line indicates a period (Days 18 through 21) during which cortisone administration continued but sodium and potassium excretion were not measured. 

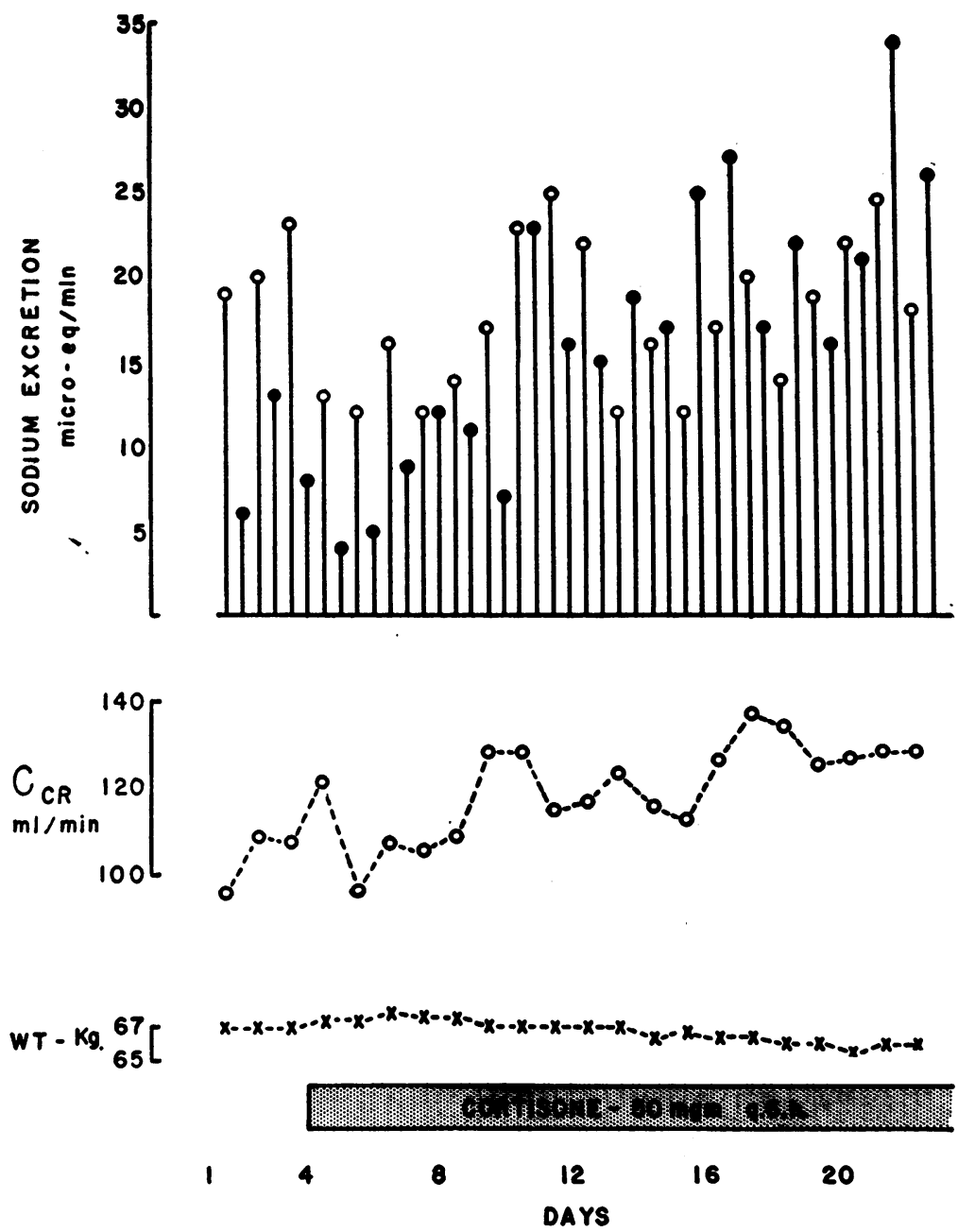

Fig. 4. Subject Z. Period IV. Serial Daily Observations of Diurnal Excretory Rhythm of Sodum Before and During Cortisone AdMinistration

Open circles represent day values. Solid circles, night values. Dietary sodium intake approximately 35 meq. Day 1 corresponds to 22nd day of entire study (Table II).

4). Nocturnal excretion of chloride increased at the same time, while the nocturnal urine flow rose to approximate the day rate 48 hours later. Thereafter, the diurnal rhythm for sodium and chloride was eliminated while salt intake remained low, and reversed when a supplement of sodium chloride was given (periods V-VII, Table II). Return to a normal excretory rhythm for sodium, chloride, and water took place by the 66th day, within a week of discontinuing the hormone (period VIII, Table II). The rhythm of potassium excretion was altered less promptly than in $\mathrm{X}$. and $Y$. The nocturnal decline in excretory rate was either very small or absent after the 35 th day of observation (11th day of therapy). The nocturnal excretory rate regularly equalled or exceeded the day rate after a nocturnal potassium supplement was added to the diet on the 39th day (period VIII, Table II). Despite continued administration of this nocturnal supplement, normal diurnal rhythmicity returned a week after treatment was discontinued and was uninfluenced by change in sodium intake (periods VIII and IX, Table II). Change in endogenous creatinine clearance was far less than in X. or Y. Some increase was observed during the first two weeks 
on cortisone (Figure 4), but it is to be noted that the clearance was highest during period VIII, when cortisone had been discontinued and a normal diurnal rhythm had reappeared.

An abnormal excretory pattern after cessation of cortisone administration was observed in $\mathrm{D}$. on his seventh and eighth post-treatment days (Table I). At this time his nocturnal rate of sodium excretion was somewhat higher than the rate by day and the nocturnal excretion of chloride almost equalled that by day. However, potassium excretion was distinctly less by night than by day, although the rate throughout the 48hour period was remarkably high, presumably because the patient was eating voraciously at the time.

\section{DISCUSSION}

The normal diurnal rhythm of renal excretory function can be demonstrated under a variety of experimental conditions and is not consistently altered by reversing or otherwise modifying the pattern of sleep and activity by day and by night $(18,19,25,30,52-54)$. The observation that when cortisone was administered the normal rhythmic excretory pattern was virtually abolished or actually reversed in each of the seven subjects indicates that this agent exerts an important action upon the mechanism responsible for the normal rhythm.

That the posture of the subject continued to exert an important influence during cortisone administration is demonstrated by the fact that the two subjects who remained recumbent throughout a 48-hour period during therapy failed to exhibit a reversal of the excretory rhythms for sodium and chloride, although the normal nocturnal suppression of excretion was decreased or eliminated. However, when these two subjects were ambulatory by day actual reversal of rhythm occurred, as it also did in four of the other five subjects who remained recumbent only during the night. In the normal individual, not receiving cortisone, assumption of the recumbent posture during the day characteristically evokes a diuresis of water, sodium, and chloride $(4,5,15,21,30$, $31,55-69)$. A similar diuresis would be expected to occur during nocturnal recumbency if the factors which maintain the normal diurnal rhythm were not operative. Modification of these factors by cortisone administration appears to permit recumbency to evoke at night the renal response that it normally induces only during the day.

There was no clear influence of posture on the change in the diurnal rhythm of potassium excretion which was eliminated or reversed in all seven subjects. Other observations concerning the renal excretion of potassium $(30,69,70)$ suggest that the influence of posture is unimportant.

Although an increase in the rate of endogenous creatinine clearance occurred during therapy (71), the absence of significant alterations in the normal small diurnal variation in its clearance rate argues against the possibility that altered patterns of water and electrolyte excretion were related to changes in the diurnal rhythm of glomerular filtration. Moreover the elevation of clearance could hardly explain the disturbance of diurnal rhythm. In subject $Y$. the pattern of potassium excretion was altered before creatinine clearance rose. In $\mathrm{X}$. creatinine clearance was not measured before cortisone was given. The clearance determined on the fifth day of cortisone administration was strikingly elevated (230 ml./ min.), but reversal of the diurnal rhythm for sodium and chloride did not occur until the 12th day of treatment. In $Z$. changes in the magnitude of clearance were small and apparently unrelated to change in diurnal rhythm. The validity of endogenous creatinine clearance as a measure of glomerular filtration rate in subjects receiving ACTH or cortisone is open to question (72), but the dissociation of the changes observed in the magnitude of creatinine clearance on the one hand, and the pattern of electrolyte excretion on the other, suggests that they are not directly interdependent.

Alterations in the patterns of excretion of sodium and of chloride were apparent both when the diet was poor in sodium and when the dietary salt intake was liberal. Conceivably, reversal of the excretory rhythm for sodium and chloride by cortisone might be related to concomitant or antecedent cumulative retention of these ions, since a similar reversal is observed when they are retained in patients with congestive heart failure $(30,33,73,74)$ or cirrhosis of the liver $(29,30$, 33). In the studies of $Y$. the period during which reversal of diurnal rhythm was apparent coin- 
cided quite closely with the period of sodium retention. The studies of $Z$., however, demonstrate that such an association is not a necessary one, since reversal of rhythm took place while he received a salt-poor diet without gain in weight or decrease in sodium excretion.

The temporal relationships of the alterations in excretory rhythm of sodium and chloride to the administration of cortisone, as defined in the studies of $\mathrm{X}$., Y. and Z., afford strong evidence that the changes cannot be attributed to an immediate direct influence of cortisone upon renal excretory function. Subjects $X$. and $Z$. continued to manifest a normal diurnal pattern for more than a week after they had been receiving cortisone in daily doses of $500 \mathrm{mg}$. Even on the 23rd and 24th days of treatment, $X$. exhibited a nocturnal fall in excretion rates of sodium and chloride during constant recumbency. In another subject (C., Table I), the nocturnal excretion of sodium and chloride remained below the rates by day after more than three weeks of cortisone administration. Persistence of abnormalities in the rhythm of sodium and chloride excretion for seven to 16 days after cortisone had been discontinued provides additional evidence that alteration in rhythm is not dependent upon the presence of large amounts of cortisone in the organism; indeed, during this post-treatment period a deficient supply of adrenocortical hormones is often evident $(45-47,51)$.

The temporal relationship of change in the pattern of potassium excretion to administration of cortisone was somewhat more suggestive of a direct influence upon the renal excretory rhythm in subject $\mathrm{Y}$. whose nocturnal excretion rates approached the day rates on the first two days of treatment and thereafter equalled or exceeded the rates by day. In $\mathrm{X}$. the normal rhythm was also eliminated on the third day of treatment. However, $Z$. maintained a normal rhythm during the first ten days of cortisone administration and all three subjects manifested an abnormal excretory rhythm for at least a week after cortisone had been discontinued.

These temporal dissociations between cortisone administration and alteration in diurnal rhythm do not support the hypothesis that the normally occurring rhythm is determined by a diurnal rhythm of endogenous adrenocortical secretory function. ${ }^{2}$ Other considerations also argue against this hypothesis. First, increased endogenous production of adrenocortical hormone due to increased liberation of $\mathrm{ACTH}$ during the morning might be expected to induce a decrease in excretion of sodium and chloride rather than the increase normally found. Stanbury and Thomson were able to produce a nocturnal increase of potassium excretion by giving a single dose of ACTH at night, but the excretory rhythm for sodium was unchanged (32). Second, although the adrenalectomized rat maintained on tap water fails to manifest the nocturnal rise of sodium excretion characteristic of intact members of this species, when saline is given, the excretory pattern of sodium is normal (42). Third, the data of Levy, Power, and Kepler (43) indicate that in untreated patients with Addison's disease the excretion of chloride and sodium increases slightly in the morning and that this matutinal increase attains normal magnitude during treatment with adrenal cortical extract or desaxycorticosterone acetate. The observations of Borst and de Vries (30) and of Slessor (44) afford additional evidence that patients with Addison's disease excrete less sodium and chloride at night than by day. Finally, a patient with Addison's disease has been studied while maintained on desoxycorticosterone acetate $(1.25 \mathrm{mg}$. intramuscularly at 6 a.m. and 6 p.m.) and cortisone (6.25 mg. orally at 6 a.m. and 6 p.m.) (85). When he remained at bed rest and took identical food and fluid every six hours day and night, the

\footnotetext{
2 The existence of such an adrenocortical rhythm in man is suggested by observations that the renal excretion of 17-ketosteroids (75-79), neutral reducing lipids (78), and uric acid $(8,36,37)$ is less at night than during the day, as well as by the fact that the numbers of circulating lymphocytes (80) and eosinophils (81-83) increase at night. It is recognized that the diurnal excretory rhythm of 17-ketosteroids and neutral reducing lipid could occur even with a constant rate of endogenous secretion of adrenocortical hormones if there were appropriate variations either in the rate at which conversion of these precursors to their excretion products took place or in the renal clearance of the excretion products (79). However, preliminary observations indicate that when large amounts of a precursor (testosterone propionate) are supplied exogenously at 12-hour intervals to normal subjects, the additional excretion of 17 -ketosteroids is not significantly greater during the day than at night (84).
} 
diurnal excretory pattern for water, sodium, chloride and potassium was essentially normal.

The above evidence permits the conclusion that the diurnal rhythm of excretion of sodium and chloride is not directly dependent upon endogenous adrenal activity, even though adrenocortical hormones may exert profound indirect influences. Nor is it probable that the normal excretory rhythm for potassium is determined by a diurnal adrenocortical rhythm. The temporal dissociation between cortisone administration and change in excretory rhythm, although less striking than in the case of sodium, is hardly consistent with the belief that the large diurnal changes in excretion of potassium which normally take place over a very few hours could be induced by change in endogenous production of cortisone-like steroid. Moreover, although in $Z$. the administration of desoxycorticosterone acetate at six-hour intervals evoked a large increase in potassium excretion, the nocturnal rates remained well below those of the day. The patient with Addison's disease studied by us exhibited a normal pattern of potassium excretion when he remained recumbent throughout a 72-hour period. Borst's and de Vries' patient exhibited a similar normal rhythm, although the magnitude of variation was less than that of a single control subject maintained under similar conditions (30). Matutinal increase in potassium excretion was absent in the untreated patients with Addison's disease reported by Levy, Power, and Kepler, but in treated patients an increase took place, although this was less than in normal subjects (43).

It would appear, therefore, that the diurnal rhythm of renal excretory function is altered by cortisone in some indirect manner. Since hypokalemic alkalosis may occur during its administration, serial determination of serum bicarbonate in the patients studied would have been of interest, particularly in view of Stanbury's and Thomson's suggestion that the excretory rhythm may be linked with cyclic changes in acid-base equilibrium (32). Alterations in the total daily excretion of water and solutes such as urea and phosphate related to increased food intake and protein catabolism during cortisone administration might induce changes in the diurnal excretory pattern. Further observations are required, but the persistence of abnormalities in the diurnal rhythm after cortisone withdrawal would make it difficult to relate the changes to such metabolic effects. The possibility that a secondary effect on the adenohypophysis is involved might be considered, since there is some evidence that the anterior pituitary plays a role in other diurnal rhythms (41), and that the excretory rhythm for chloride may be abnormal in patients with panhypopituitarism (44). Mills has suggested that rhythmic activity of the hypothalamus may be responsible for diurnal variation in urine flow (53). Since cortisone may have pronounced cerebral effects $(45,46)$, including disturbance of normal sleep patterns, and since the central nervous system appears to have important influences on the excretion of electrolyte as well as of water (8692 ), it is possible that its neurological action may be involved in producing the changes we have observed.

\section{SUMMARY AND CONCLUSIONS}

1. The influence of cortisone administered in divided daily doses of 200 or $500 \mathrm{mg}$. upon the diurnal variation in renal excretion of water, sodium, potassium, chloride, and creatinine has been studied in seven patients free from renal or cardiovascular disease. One of these patients was also observed during the administration of desoxycorticosterone acetate in divided daily doses of $40 \mathrm{mg}$.

2. The diurnal excretory rhythm was not altered during administration of desoxycorticosterone.

3. During cortisone therapy when the subjects were ambulatory, the normal diurnal rhythm of renal water excretion was reversed in five of the seven patients and virtually eliminated in the others. The excretory rhythm of sodium and chloride was reversed in six patients. The normal rhythm of potassium excretion was eliminated in all seven and reversed in three of these. No significant change occurred in the pattern of creatinine excretion.

4. In two subjects at bed rest who ate identical meals every six hours, the diurnal excretory rhythm for potassium was eliminated in both, but one continued to manifest nocturnal suppression of sodium and chloride excretion.

5. The temporal sequence of the changes was studied in three of the subjects before, during, 
and after the course of cortisone administration. The observations seem most consistent with the belief that the changes in excretory rhythm are not the result of a direct action of cortisone upon the renal excretory mechanism.

6. The normal diurnal rhythm of renal excretion does not appear to depend upon rhythmic changes in endogenous adrenocortical secretion, although the demonstration that striking changes occur when large amounts of exogenous adrenal steroid are given suggests that endogenous adrenal hormone may also exert important modifying influences.

\section{ACKNOWLEDGMENTS}

The technical assistance of Miss Regina McLean and Miss Miriam E. Halpin is gratefully acknowledged.

\section{REFERENCES}

1. Vogel, J., Klinische Untersuchungen über den Stoffwechsel bei gesunden und kranken Menschen überhaupt, und den durch den Urin in besondere. Arch. d. Vereins f. wissensch. Heilk., 1854, 1, 96.

2. Roberts, W., Observations on some of the daily changes of urine. Edinburgh M. J., 1860, 5, 817.

3. Quincke, H., Ueber den Einfluss des Schlafes auf die Harnabsonderung. Arch. f. exper. Path. u. Pharmakol., 1877, 7, 115.

4. Laehr, H., Versuche über den Einfluss des-Schlafes auf den Stoffwechsel. Allg. Ztschr. f. Psychiat., 1889, 46, 286.

5. Quincke, H., Ueber Tag- und Nachtharn. Arch. f. exper. Path. u. Pharmakol., 1893, 32, 211.

6. Chauffard, A., and Castaigne, J., L'Épreuve du bleu et les éliminationes urinaires chez les hepatiques. J. de physiol. et de path. gén., 1899, 1, 476.

7. Wilson, C., On diurnal and nocturnal excretion of urine. Lancet, 1889, 1, 1299.

8. Speck, Untersuchungen über die Beziehungen der geistigen Thätigkeit zum Stoffwechsel. Arch. f. exper. Path. u. Pharmakol., 1881, 15, 81.

9. Roberts, W., A Practical Treatise on Urinary and Renal Diseases. Smith, Elder \& Co., London, 1885, Ed. 4, pp. 23-27.

10. Gley, E., and Richet, C., Expériences sur la courbe horaire de l'urée et le dosage de l'azote total de l'urine. Compt. rend. soc. de biol., 1887, 8s., IV (39), 377.

11. Posner, C., Das Verhalten der Harnabsonderung während der Nacht. Arch. f. Physiol., 1887, 389.

12. Roger, H., Note sur les variations quotidiennes de l'urine et de l'urée. Arch. de physiol. norm. et path., 1895, 5s., VII (27), 500.

13. Laspeyres, R., Ueber Tag- und Nachtharn. Deutsches . Arch. f. klin. Med., 1900, 68, 175.
14. Yvon, M., Sur les variations horaires de l'excrétion urinaire chez l'homme normal. Compt. rend. soc. de biol., 1901, 53, 201.

15. Vaquez, H., and Cottet, J., Recherches et considérations cliniques sur le rythme de la sécrétion urinaire et sur la diurèse provoquée par ingestion d'eau (polyurie experimentale). Rev. de méd., 1910, 30, 520.

16. Hegar, A., Ueber die Ausscheidung der Chlorverbindungen durch den Harn. Diss. inaug., Giessen, 1852. (Abstr.) Arch. des Vereins f. wissensch. Heilk., 1854, 1, 665 .

17. Campbell, J. A., and Webster, T. A., Day and night urine during complete rest, laboratory routine, light muscular work and oxygen administration. Biochem. J., 1921, 15, 660.

18. Campbell, J. A., and Webster, T. A., Note on urinary tides and excretory rhythm. Biochem. J., 1922, 16, 507.

19. Kleitman, N., Studies on the physiology of sleep. I. The effects of prolonged sleeplessness on man. Am. J. Physiol., 1923, 66, 67.

20. Simpson, G. E., Diurnal variations in the rate of urine excretion for two hour intervals: some associated factors. J. Biol. Chem., 1924, 59, 107.

21. Bazett, H. C., Thurlow, S., Crowell, C., and Stewart, W., Studies on the effects of baths on man. II. The diuresis caused by warm baths, together with some observations on urinary tides. Am. J. Physiol., 1924, 70, 430.

22. Simpson, G. E., The effect of sleep on urinary chlorides and $\mathrm{pH}$. J. Biol. Chem., 1926, 67, 505.

23. Norn, M., Untersuchung über das Verhalten des Kaliums in Organismus. II. Uber Schwankungen der Kalium-, Natrium- und Chloridausscheidung durch die Niere im Laufe des Tages. Skandinav. Arch. f. Physiol., 1929, 55, 184.

24. Manchester, R. C., The diurnal rhythm in water and mineral exchange. J. Clin. Invest., 1933, 12, 995.

25. Jores, A., Physiologie und Pathologie der 24-StundenRhythmik des Menschen. Ergebn. d. inn. Med. u. Kinderh., 1935, 48, 574.

26. Gerritzen, F., Der 24-Stunden-Rhythmus der Chlorausscheidung. Arch. f. d. ges. Physiol., 1937, 238, 483.

27. Gerritzen, F., Der 24-Stundenrhythmus in der Diurese. Deutsche med. Wchschr., 1938, 64, 746.

28. Gerritzen, F., The rhythmic function of the human liver. Acta med. Scandinav., 1940, Supp. 108, 121.

29. Smits, J. A., Bijdrage tot het onderzoek van het 24uursrhytme bij de mens. Thesis, Amsterdam, 1948.

30. Borst, J. G. G., and de Vries, L. A., The three types of "natural" diuresis. Lancet, 1950, $2,1$.

31. Blomhert, G., Over de Zogenaamde Waterdiurese. Thesis, Amsterdam, 1951.

32. Stanbury, S. W., and Thomson, A. E., Diurnal variations in electrolyte excretion. Clin. Sc., 1951, 10, 267. 
33. Goldman, R., Studies in diurnal variation of water and electrolyte excretion: nocturnal diuresis of water and sodium in congestive cardiac failure and cirrhosis of the liver. J. Clin. Invest., 1951, 30, 1191.

34. Bert, P., Sur les phases horaire d'excrétion de l'urine et de l'urée; sur les variations de l'urée en rapport avec la nourriture; sur les rapports entre la richesse en urée et sa coloration. Compt. rend. Soc. de biol., 1878, 30, 255.

35. Cohen, I., and Dodds, E. C., Twenty-four hour observations on the metabolism of normal and starving subjects. J. Physiol., 1924, 59, 259.

36. Leathes, J. B., On diurnal and nocturnal variations in the excretion of uric acid. J. Physiol., 1906-7, 35, 125 .

37. Cathcart, E. P., Kennaway, E. L., and Leathes, J. B., On the origin of endogenous uric acid. Quart. J. Med., 1907-8, 1, 416.

38. Simpson, G. E., Changes in the composition of urine brought about by sleep and other factors. J. Biol. Chem., 1929, 84, 393.

39. Addis, T., Barrett, E., Poo, L. J., Ureen, H. J., and Lippman, R. W., The relation between protein consumption and diurnal variations of the endogenous creatinine clearance in normal individuals. J. Clin. Invest., 1951, 30, 206.

40. Sirota, J. H., Baldwin, D. S., and Villarreal, H., Diurnal variations of renal function in man. J. Clin. Invest., 1950, 29, 187.

41. Kleitman, N., Biological rhythms and cycles. Physiol. Rev., 1949, 29, 1.

42. Simpson, S. A., and Tait, J. F., Dose response studies of the effect of desoxycorticosterone acetate (DOCA) on the sodium excretion of adrenalectomized rats. Endocrinology, 1950, 47, 308.

43. Levy, M. S., Power, M. H., and Kepler, E. J., The specificity of the "water test" as a diagnostic procedure in Addison's disease. J. Clin. Endocrinol., 1946, 6, 607.

44. Slessor, A., Studies concerning the mechanism of water retention in Addison's disease and hypopituitarism. J. Clin. Endocrinol., 1951, 11, 700.

45. Sprague, R. G., Power, M. H., Mason, H. L., Albert, A., Mathieson, D. R., Hench, P. S., Kendall, E. C., Slocumb, C. H., and Polley, H. F., Observations on the physiologic effects of cortisone and ACTH in man. Arch. Int. Med., 1950, 85, 199.

46. Sprague, R. G., Cortisone and ACTH. A review of their physiologic effects and their clinical implications. Am. J. Med., 1951, 10, 567.

47. Sayers, G., Regulation of pituitary adrenocorticotropic activity, in Tr. Second Conf. on Adrenal Cortex (1950). Josiah Macy, Jr., Found., New York, 1951, pp. 48-87.

48. Peters, J. P., and Van Slyke, D. D., Quantitative Clinical Chemistry. Vol. II, Methods. Williams \& Wilkins, Baltimore, 1932, pp. 832-835.

49. Peters, J. H., The determination of creatinine and creatine in blood and urine with the photoelectric colorimeter. J. Biol. Chem., 1942, 146, 179.

50. Hare, R. S., Endogenous creatinine in serum and urine. Proc. Soc. Exper. Biol. \& Med., 1950, 74, 148.

51. Perera, G. A., Fleming, T. C., Pines, K. L., and Crymble, M., Cortisone in hypertensive vascular disease. J. Clin. Invest., 1950, 29, 739.

52. Jores, A., Die Urinschränkung in der Nacht. Deutsches Arch. f. klin. Med., 1933, 175, 244.

53. Mills, J. N., Diurnal rhythm in urine flow. J. Physiol., 1951, 113, 528.

54. Mills, J. N., and Stanbury, S. W., Intrinsic diurnal rhythm in urinary electrolyte output. J. Physiol., 1951, 115, 18P.

55. Wendt, E., Ueber den Einfluss des intraabdominalen Druckes auf die Absonderungsgeschwindigkeit des Harnes. Arch. d. Heilk., 1876, 17, 527.

56. Edel, P., "Cyklische" Albuminurie und neue Gesichspunkte für die Bekämpfung von Albuminurien. München. med. Wchnschr., 1901, 48, 1833, 1884.

57. Linossier, G., and Lemoine, G.-H., (a). Influence de l'orthostatisme sur le fonctionnement du rein. Compt. rend. Soc. de biol., 1903, 55, 466. (b) Influence de l'orthostatisme sur la sécrétion urinaire au point de vue séméiologique. Ibid., 469.

58. Erlanger, J., and Hooker, D. R., An experimental study of the blood pressure and pulse pressure in man. Johns Hopkins Hosp. Rep., 1904, 12, 145.

59. Loeb, A., Klinische Untersuchungen über den Einfluss von Kreislaufsänderungen auf die Urinzusammensetzung. I. Zur Kenntnis der orthostatischen Albuminurie. Deutsches Arch. f. klin. Med., 1905, 83, 452.

60. Linossier, G., and Lemoine, G.-H., Mécanisme de l'albuminurie et de l'oliguria orthostatique. Bull. et mém. Soc. méd. d. hôp. de Paris, 1909, Ser. 3, 27, 565.

61. Adolph, E. F., The regulation of the water content of the human organism. J. Physiol., 1921, 55, 114.

62. Neukirch, P., and Neuhaus, K., Der Einfluss aufrechter Körperhaltung auf die Diurese Herz- und Nierengesunder. Deutsche med. Wchnschr., 1922, 48, 1413.

63. Seyderhelm, R., and Goldberg, E., Uber die Beziehungen der extrarenalen Wasserausscheidung im Wasser- und Salzwasser-Trinkversuch. Ztschr. f. klin. Med., 1926, 103, 161.

64. White, H. L., Rosen, I. T., Fischer, S. S., and Wood, G. H., The influence of posture on renal activity. Am. J. Physiol., 1926, 78, 185.

65. Ni, T. G., and Rehberg, P. B., On the influence of posture on kidney function. J. Physiol., 1931, 71, 331.

66. Asmussen, E., Christensen, E. H., and Nielsen, M., Uber die Kreislaufinsuffizienz in stehender Stellung bei normalen arteriellen Druck und herabgesetztem Minutenvolumen. Skandinav. Arch. f. Physiol., 1939, 81, 214. 
67. Asmussen, E., Christensen, E. H., and Nielsen, M., The regulation of the circulation in different postures. Surgery, 1940, 8, 604.

68. Brun, C., Knudsen, E. O. E., and Raaschou, F., Influence of posture on kidney function. I. The fall in the diuresis in the erect posture. Acta med. Scandinav., 1945, 122, 315.

69. Kattus, A. A., Sinclair-Smith, B., Genest, J., and Newman, E. V., The effect of exercise on the renal mechanism of electrolyte excretion in normal subjects. Bull. Johns Hopkins Hosp., 1949, 84, 344.

70. Rosenbaum, J. D., Davis, R. K., and Ferguson, B. C., Unpublished observations.

71. Rosenbaum, J. D., Davis, R. K., and Ferguson, B. C., The influence of cortisone on water diuresis in man. J. Clin. Invest., 1951, 30, 668.

72. Burnett, C. H., The actions of ACTH and cortisone on renal function in man, in Tr. Second Conf. on Renal Function (1950). Josiah L. Macy, Jr., Found., New York, 1951, pp. 106-126.

73. Baldwin, D. S., Sirota, J. H., and Villarreal, H., Diurnal variations of renal function in congestive heart failure. Proc. Soc. Exper. Biol. \& Med., 1950, 74, 578.

74. Fejfar, Z., and Brod, J., The excretion of chlorides in patients with heart failure. Quart. J. Med., 1950, 19, 221.

75. Pincus, G., A diurnal rhythm in the excretion of urinary ketosteroids by young men. J. Clin. Endocrinol., 1943, 3, 195.

76. Wooster, H., A biometric study of total neutral 17ketosteroid excretion in the normal adult male. J. Clin. Endocrinol., 1943, 3, 483.

77. Forbes, A. P., Donaldson, E. C., Reifenstein, E. C., Jr., and Albright, F., The effect of trauma and disease on the urinary 17-ketosteroid excretion in man. J. Clin. Endocrinol., 1947, 7, 264.

78. Pincus, G., Romanoff, L. P., and Carlo, J., A diurnal rhythm in the excretion of neutral reducing lipids by man and its relation to the 17-ketosteroid rhythm. J. Clin. Endocrinol., 1948, 8, 221.

79. Mason, H. L., and Engstrom, W. W., The 17-ketosteroids: their origin, determination and significance. Physiol. Rev., 1950, 30, 321.

80. Elmadjian, F., and Pincus, G., A study of the diurnal variations in circulating lymphocytes in normal and psychotic subjects. J. Clin. Endocrinol., 1946, 6, 287.

81. Rud, F., The eosinophil count in health and in mental disease; biometrical study. Acta psychiat. et neurol., 1947, Supp. 40.

82. Herbert, P. H., and de Vries, J. A., The administration of adrenocorticotrophic hormone to normal human subjects. The effect on the leucocytes in the blood and on circulating antibody levels. Endocrinology, 1949, 44, 259.

83. Best, W. R., and Samter, M., Variation and error in eosinophil counts of blood and bone marrow. Blood, 1951, 6, 61.

84. Papper, S., and Rosenbaum, J. D., Unpublished observations.

85. Rosenbaum, J. D., Ashley, M. M., and Ferguson, B. C., Unpublished observations.

86. Lewy, F. H., and Gassmann, F. K., Experiments on the hypothalamic nuclei in the regulation of chloride and sugar metabolism. Am. J. Physiol., 1935, 112, 504.

87. Allott, E. N., Sodium and chlorine retention without renal disease. Lancet, 1939, 1, 1035.

88. Luetscher, J. A., Jr., and Blackman, S. S., Jr., Severe injury to kidneys and brain following sulfathiazole administration: high serum sodium and chloride levels and persistent cerebral damage. Ann. Int. Med., 1943, 18, 741.

89. Sweet, W. H., Cotzias, G. C., Seed, J., and Yakovlev, P. I., Gastro-intestinal hemorrhages, hyperglycemia, azotemia, hyperchloremia and hypernatremia following lesions of the frontal lobe in man. A. Research Nerv. \& Ment. Dis., Proc., 1948, 27, 795.

90. Peters, J. P., Welt, L. G., Sims, E. A. H., Orloff, J., and Needham, J., A salt-wasting syndrome associated with cerebral disease. Tr. A. Am. Physicians, 1950, 63, 57.

91. MacCarty, C. S., and Cooper, I. S., Neurologic and metabolic effects of bilateral ligation of the anterior cerebral arteries in man. Proc. Staff Meet., Mayo Clinic, 1951, 26, 185.

92. Higgins, G., Lewin, W., O’Brien, J. R. P., and Taylor, W. H., Metabolic disorders in head injury. Hyperchloraemia and hypochloruria. Lancet, 1951, 1, 1295. 